\title{
STUDI KASUS PENJUALAN KOSMETIK MENGGUNAKAN METODE ASSOCIATION RULE (APRIORI)
}

\author{
Warisa $^{1}$, Siti Aminah ${ }^{2}$, Karmila ${ }^{3}$ \\ ${ }^{1}$ Fakultas Ilmu Komputer, Universitas Darwan Ali \\ email: wewarisa020@gmail.com \\ ${ }^{2}$ Fakultas Ilmu Komputer, Universitas Darwan Ali \\ email: Sity5081@gmail.com \\ ${ }^{3}$ Fakultas Ilmu Komputer, Universitas Darwan Ali \\ email: karmilafikom234@gmail.com
}

\begin{abstract}
ABSTRAK
Dengan berkembangnya teknologi yang semakin maju membuat banyaknya persaingan dalam dunia perdagangan kosmetik. Seperti pada online shop Atika Kosmetik yang menjual berbagai macam produk kosmetik, yang mana dalam pendataan suatu produknya masih menggunakan hitungan secara manual. Sehingga sulit dalam mengetahui produk kosmetik yang sudah terjual serta sulit mengetahui kosmetik yang sudah tidak tersedia, Oleh karena itu dilakukan penerapan metode Association Rule (algoritma apriori) untuk mengetahui kombinasi produk yang mempermudah mengelola data penjualan kosmetik. Agar lebih mudah mengetahui jenis produk yang masih tersedia dan kosmetik yang paling banyak terjual. Maka dari itu dilakukan penerapan metode data mining Association Rule (algoritma apriori) dengan menggunakan software Weka dalam pengolahan data. Data transaksi penjualan online shop atika Kosmetik dari tahun 2020 - 2021 sebagai bahan analisa pada penelitian ini. Dengan perhitungan algoritma apriori maka hasil yang diperoleh pada produk paling sering dibeli oleh pembeli yaitu cream tabita glow, cream ms glow, serum glow, lipstick Maybelline serum hanusui, hanbody syi lotion, bibit pemutih badan, obat gemuk herbal dan obat kurus herbal dan lainnya.
\end{abstract}

Keywords: Data Mining, Association Rule, A priori algorithm, Online shop Atika.

\section{PENDAHULUAN}

Banyaknya kegiatan perdagangan produk kosmetik secara online menjadi bagian yang tidak lepas dalam Perawatan kecantikan untuk kalangan para wanita, karena kecantikan merupakan bagian terpenting dari gaya hidup wanita. Biasanya kosmetik yang dibeli di pasaran, kini dapat dibeli secara online tanpa langsung datang ke toko yang mempermudah konsumen dalam pembelian produk kosmetik. Kekurangan dari jual beli secara online yaitu membuat penjual bisa lupa dalam pencatatan hasil penjualan, dan sulit melihat produk yang banyak diminati oleh pembeli. Untuk itu dalam pemecahan masalah ini, diperlukan metode Association Rule Algoritma Apriori dalam pengolahan datanya.

\section{Association Rule Algoritma Apriori} merupakan suatu metode dalam pencarian pola hubungan antara satu maupun lebih item atau barang dalam suatu dataset. Algoritma apriori banyak sekali digunakan pada data penjualan (market basket), misalnya sebuah minimarket yang memiliki market basket. Pemilik minimarket bisa mengetahui pola pembelian 
seorang pelanggan, dengan adanya algoritma apriori.

Online shop Atika adalah salah satu agen kosmetik yang ada di kota sampit, online shop atika menjual produk kecantikan dan juga obat herbal untuk Kesehatan wanita maupun lakilaki. Dari penjualan produk kosmetik atika tersebut terjadi transaksi jual beli di antara penjual dan pembeli, produk kosmetik ini sangat luas di kalangan masyarakat (terutama di kalangan wanita), oleh karena itu produk kecantikan sangat di minati oleh para jutaan wanita, dan dengan adanya sebuah sistem informasi sangat membantu untuk mempermudahkan transaksi penjualan kosmetik Online shop Atika.

Penjualan kosmetik di lapak pemasaran sangat memperluas pemasaran produk kecantikan sehingga memungkinkan meningkatnya penjualan di pasaran kalangan masyarakat dengan melalui penjualan secara online, karena dengan adanya sistem pembelian secara online ataupun memesan barang melalui handphone kita sendiri bisa membantu mempermudahkan kita berjualan agar kita tidak perlu keluar rumah lagi, dengan mengunakan Handphone milik kita sendiri bisa melakukan pembelian produk kecantikan ataupun barang lainnya secara online, agar bisa memesan berbagai macam produk kecantikan dan produk lainnya yang di inginkan konsumen.

Dari hasil penjualan online shop akan ada transaksi jual beli dan itu membuat online shop Jurnal Ilmiah "Technologia"
Atika memiliki data persediaan barang dan juga data transaksi penjualan kosmetik yang selalu ada di setiap harinya. Sehingga data transaksi penjualan produk kosmetik menyebabkan data menumpuk, di karenakan transaksi penjualan yang selalu ada di setiap harinya, pemecahan masalah ini dapat di lakukan dengan cara di lakukan dengan cara mengelola peningkatan penjualan produk kosmetik Atika, yaitu juga dapat dilakukan dengan cara mengelolah data dari online shop Atika tersebut, dengan menggunakan data transaksi yang menumpuk menjadi sebuah informasi yang berguna. Jadi informasi yang berguna tersebut dapat digunakan untuk membuat sebuah strategis penjualan dan menghasilkan sebuah bisnis secara online dengan menerapkan data penjualan produk tersebut menjadi sebuah strategis bisnis penjualan produk kecantikan dan yang lainnya. Dalam menganalisis transaksi penjualan bertujuan untuk merancang sebuah strategi penjualan yang efektif dengan memanfaatkan data transaksi pada online shop Atika.

Selain itu menggunakan teknik analisis data online shop Atika ini juga dapat menemukan data produk yang sering dibeli pelanggan dalam sebuah transaksi jual beli. Pembuatan data penjualan produk tersebut untuk memperoleh informasi mengenai cara yang dapat dilakukan dengan menggunakan datamining, metode Association Rules (Algoritma Apriori) dan metode Association Rules sangat cocok digunakan pada data online shop Atika. 


\section{RUMUSAN MASALAH}

Adapun rumusan masalah yang diambil penulis menganalisis kasus penjualan kosmetik menggunakan metode Association Rule (algoritma Apriori). Dan menggunakan aplikasi weka untuk menganalisa hasil penjualan produk kosmetik tersebut.

\section{TUJUAN}

Tujuan penelitian ini adalah untuk menerepakan metode Association Rule (algoritma Apriori) pada studi kasus penjualan kosmetik. Karena banyak kasus

Pejualan kosmetik yang tidak teratur jadi penulis menggunakan metode Asociation rule.

\section{MANFAAT PENELITIAN}

untuk menambah pengetahuan dalam menggunakan metode Association Rule(apriori).

* Sebagai pemasukan data dan informasi dalam usaha online shop Atika tersebut.

Memberikan manfaat bagi pemilik usaha online shop agar kedepanya lebih mudah dalam mengakses data.

\section{METODOLOGI PENELITIAN}

Metodologi merupakan hal yang sangat penting dalam menganalisis suatu data pada Online shop Atika dengan menggunakan metode Association rule (algoritma apriori), untuk mengetahui permasalahan tersebut harus di lakukan dengan Teknik pengumpulan data dengan melakukan penelitian dan melihat secara langsung pada produk kosmetik tersebut.

\section{TINJAUAN PUSTAKA}

Algoritma Priori termasuk jenis aturan asosiasi pada data mining. Selain priori, yang termasuk pada golongan ini adalah metode generalized rule induction dan algoritma hash based. Aturan yang menyatakan asosiasi antara beberapa atribut sering disebut affinity analysis atau market basket analysis. Analisis asosiasi atau association rule mining adalah teknik data mining untuk menemukan aturan assosiatif antara suatu kombinasi item. Contoh aturan assosiatif dari analisa pembelian di suatu minimarket adapun minimarket adalah dapat diketahuinya berapa besar kemungkinan seorang pelanggan membeli roti bersamaan dengan susu. Dengan pengetahuan tersebut pemilik toko minimarket dapat mengatur penempatan barangnya atau merancang kampanye pemasaran dengan memakai kupon diskon untuk kombinasi barang tertentu.

\section{PEMBAHASAN}

WEKA (Waikato Environment for Knowledge Analysis) adalah sebuah software yang menggunakan algoritma machine learning untuk melakukan proses data mining. Ada sejumlah fitur unggulan di WEKA yang dapat dioptimalkan guna memudahkan penggalian informasi pada basis data yang tersedia. Salah satunya, fitur regression, yaitu sebuah proses untuk memperkirakan masa yang akan datang berdasarkan pola yang sudah terbentuk. Pola 
tersebut berfungsi sebagai model data. Fitur lainnya adalah clustering yang bertujuan untuk mengelompokkan data yang tersedia. Dari proses clustering akan didapatkan pola tertentu berdasarkan hubungan antara data-data tersebut. WEKA menampilkan hasil data mining dalam bentuk chart atau gambar sehingga mudah dipahami. Selain itu, user interface/user experience aplikasi ini sederhana sehingga gampang digunakan. berikut data dari Online shop Atika :

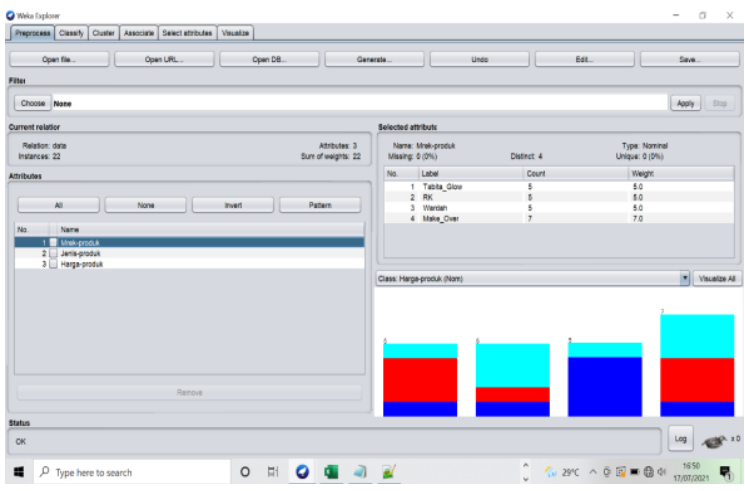

Gambar 1.Tampilan atribut merek produk

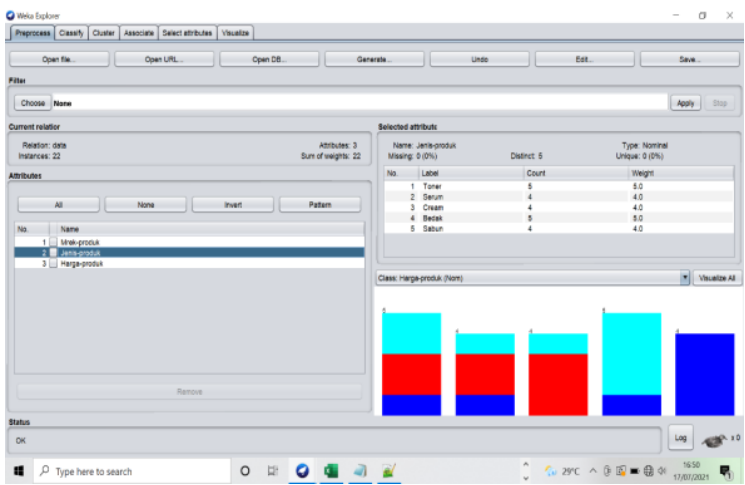

Gambar 1.1 Tampilan atribut jenis produk

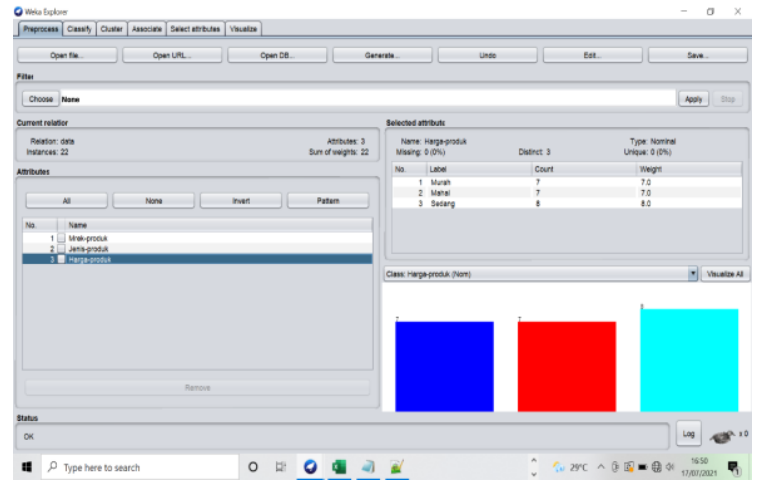

Gambar 1.2 Tampilan atribut harga produk

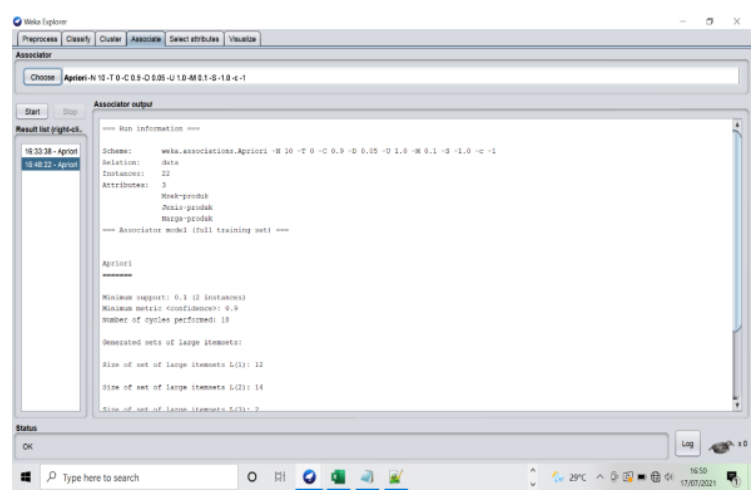

Gambar 1.3 Tampilan hasil pengolahan data ke algoritma Apriori

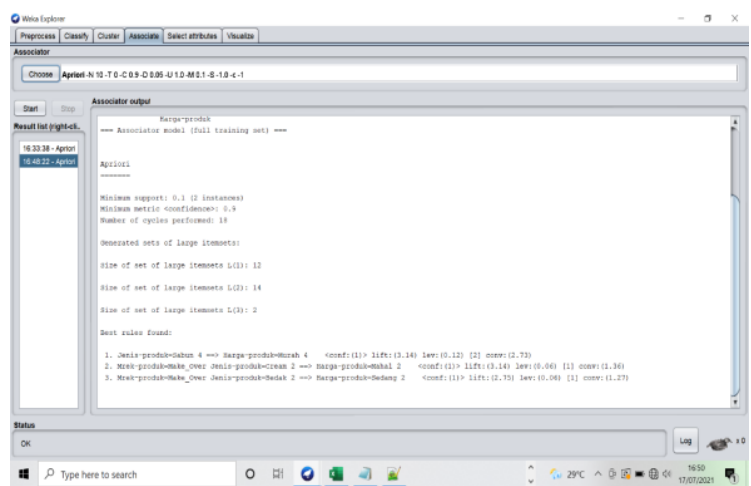

Gambar 1.3 Tampilan hasil pengolahan data ke algoritma Apriori

\section{KESIMPULAN}

Setelah melakukan pengujian dengan cara perhitungan otomatis dengan menggunakan software Weka, maka dapat disimpulkan hasil yang diperoleh adalah

1. Jenis-produk=Sabun $4==$ Hargaproduk=Murah 4 dengan conf:(1), 
2.Mrek-produk=Make_Over Jenis-

produk=Cream 2 ==> Harga-produk=Mahal 2 dengan conf:(1)

3. Mrek-produk=Make_Over Jenisproduk=Bedak $2==>$ Harga-produk=Sedang 2 dengan conf:(1)

Dapat diketahui produk yang sering dibeli adalah sabun dengan harga yang 'Murah' maka Online Shop Atika bisa mengembangkan dan mengatur strategi pemasaran stok barang, agar lebih mudah mencari barang atau produk yang diinginkan konsumen.

\section{DAFTAR PUSTAKA}

[1] Sari, N. P., \& Intan , Y. (2020, juli). REKOMENDASI PENJUALAN PAKET KOSMETIK MENGGUNAKAN ALGORITMA IMPROVISASI APRIORI. Jurnal Informatika dan Sistem Informasi, 1, 499-509.

[2] Ulkhairi, M. (2020, juli). IMPLEMENTASI DATA MINING PENJUALAN KOSMETIK DENGAN ALGORITMA APRIORI. SKRIPSI, 1-42.

[3] Wardani, F. A., \& Kristiana, T. (2020, Maret). Implementasi Data Mining Penjualan Produk Kosmetik Pada PT. Natural Nusantara Menggunakan Algoritma Apriori. Paradigma - Jurnal Informatika dan Komputer, 22, 85-90.

[4] Lutfin, C. F. (2020, juni). STRATEGI KOMUNIKASI PEMASARAN. skripsi, 1-74.

[5] Pramitha3, S. N. (2019). DATA MINING UNTUK MENENTUKAN PRODUK TERLARIS MENGGUNAKAN METODE
NAIVE BAYES. Jurnal Informasi Dan Komputer, 7, 57-64.

[6] Worotitjan, H. G. (2014). KONSTRUKSI KECANTIKAN DALAM IKLAN. JURNAL EKOMUNIKASI, 2.

[7] Zulkifli, B. D. (n.d.). PERANCANGAN APLIKASI DATA MINING UNTUKMENGANALISA PRODUK KOSMETIK DAN KECANTIKAN MENGGUNAKAN ALGORITMA APRIORI PADA PT RAJAWALI MUTIARA SEJAHTERA. Jurnal Satya Informatika, 1, 5658 . 